\title{
An Exploration of the Worldview of Addiction and the Therapeutic Experience Using Play Therapy Sessions Among Recovering Adolescents
}

\author{
Mohd Hatta Othman ${ }^{1}, \mathrm{Ku}$ Suhaila Ku Johari ${ }^{1 *}$, Mohamad Isa Amat ${ }^{2}$, Zuraidah Ayob $^{3}$ \\ ${ }^{1}$ Universiti Kebangsaan Malaysia, Bangi and Malaysia, \\ ${ }^{2}$ Asian Centre for Research on Drug Abuse (ACREDA), Fakulti Kepimpinan dan Pengurusan, Universiti Sains Islam \\ Malaysia, \\ ${ }^{3}$ Agensi Anti Dadah Kebangsaan Malaysia \\ *Corresponding author. Email: suhaila@ukm.edu.my
}

\begin{abstract}
Substance abuse among adolescents at increasingly younger ages is alarming. The use and abuse of drugs and other substances for other than medical purposes may contribute to many negative consequences, including academic drop out and health problems. This study discusses the worldview of substance abuse addiction, the contributing factors, the addiction world, and the effects of substance addiction among adolescents. A qualitative case study was conducted on four respondents aged between 14 to 16 years old in understanding their experiences and interpretation on substance abuse addiction and therapeutic experience in play therapy sessions. Data were triangulated through play therapy and unstructured interviews with the respondents during the counselling sessions. The findings showed that peer influence and family conflicts were key driving factors to drug abuse. Drug addicts preferred places that were hidden from the community. The psychological effects of adolescent substance abuse were also identified. The benefits and efficacy of using the play therapy approach in recovering addicts is promising and should be further researched.
\end{abstract}

Keywords: Play therapy, addiction counselling, adolescent substance abuse

\section{INTRODUCTION}

Drug abuse in Malaysia is reaching an alarming rate and is a national threat. In 2017 alone, more than 27,000 recovering addicts were registered with the National Anti-Drugs Agency, Agensi Anti-Dadah Kebangsaan (AADK), MyAADK (AADK, 2017). Jamaludin Ahmad (2009) states that the negative impacts of substance abuse involves the damage to individuals, families and communities. Substance abuse knows not the affected victim. According to Rusniah Ahmad et. Al. (2011), recovering addicts usually suffered from physical and psychological withdrawals during the early rehabilitation process.

Adolescence is a challenging stage where one battles with identity and role confusion (Dunkel, \& Harbke, 2017). According to Mahmood Nazar Mohamed et al. (2008) \&Hong Kian Sam et.al, 2011 this trend has also been observed in Malaysia, and the number of adolescents involved in substance abuse has increased According to Nurfarhah Mohd Najib et.al (2017) contributing factors to children who have a tendency to drug addiction come from families as well as affect the relationship and dynamics in the family to the emotions of children.
Failure of family function, poverty and insecure neighbourhoods are said to be antecedents of risk to adolescents. Within a certain period of time, children and adolescents who grow up in these risky environments are said to be more vulnerable to being fragile, inefficient, and having low endurance. A fragile personality or having low endurance, in turn, causes these children and adolescents to fail to adjust their behaviour when faced with a pressing atmosphere, and they are at risk of engaging in future problems (Garmezy 1991; Mohammad Nasir Bistamam et .al, 2015). Another study conducted by Mohammad Nasir Bistamam et. al (2015) showed that $32.9 \%$ of respondents engaged in recreational drug use, including smoking or sniffing drugs, taking the addictive substance material, associating with marijuana smokers and drinking kratom water. The resulting profile also indicates that male teens are more likely to take drugs than women.

Multiple efforts have been undertaken by various parties, especially the government, in addressing the problem of drug abuse. Teenagers are one of the contributors to the rate of increase in drug abuse. Many studies have been carried out on the use of play therapy. Play therapy is seen as one of the creative approaches in counselling that can help individuals secure 
psychological treatment through therapeutic relationships between counsellors and clients (Landreth, 2011). Safe and non-threatened therapeutic relationships between clients and counsellors during the session helps facilitate this contact process. In Malaysia, counselling services require innovation with this latest modality especially in dealing with cases involving children and adolescents. This kind of intervention allows children to express themselves safely and comfortably. Play therapy is also an effective way for counsellors to explore the world of therapeutic or meaningful childhood experiences $(\mathrm{Ku}$ Suhaila \& Mohamad Isa, 2017).

The Objectives are to explore the factors that influence adolescent involvement in drug abuse through play therapy modality, to explore the worldview of drug addiction among adolescent drug abuse through play therapy sessions and to explore the therapeutic experience of play therapy using sand tray.

\section{METHOD}

This research was conducted qualitatively using a case study design to answer questions about a phenomenon to be studied (Cresswell, 1998; Cresswell, 2012). The participants of this study were four teenagers involved with drug addiction problems who received residential drug treatment from the National Anti-Drug Agency at the Cure \& Care clinic in Kota Bharu, Kelantan.

The sand tray therapy method has six implementing protocols, namely: 1 . providing space equipped with sand tray equipment, 2 . introducing the sand tray to the client, 3 . arranging the miniatures in the sand tray, 4. sandsharing and exploration of tray, 5. termination and cleaning the sand tray, and 6. documenting the session through counselling reports (Homeyer \& Sweeney, 2016).

A total of four group counselling sessions were conducted, structured to the participants of the study based on four goals - self, family, support system and hope. Each session lasted for one hour. Each member then developed miniatures on the sand tray based on the goals of each session and the sharing and exploration of the sand tray. At the end of the group sessions, the participants of the study gave meaning to every miniature through the exploration and portrayal of the sand tray.

Participants of the study were four clients who had been involved with drug addiction at the beginning of their age.

In this study, data were obtained from in-depth interviews and observations on the process of sand tray therapy during the play therapy group counselling session.

There are many different ways to approach thematic analysis (e.g.Alhojailan, 2012; Boyatzis,1998; Javadi \& Zarea, 2016). The researchers employed Atlas. Ti to run the thematic analysis method for all three data collection techniques. Data analysis was completed by using the Three C's; Analysis of Coding, Categorizing and Concepts.

\section{FINDINGS}

The findings were based on structured group counselling sessions and activities conducted on four study participants with a counsellor. In this study, four results of the play therapy sessions were obtained. Through this approach, the participants were required to take and arrange miniatures in the sand tray provided. Pictures 1 - 4 was the result of clients No. 1 (C1) - No. 4 (C4), respectively. Table 1 shows the demographic information of the participants:

Table 1: Demographic Information

\begin{tabular}{|c|c|c|c|c|}
\hline $\begin{array}{c}\text { Client's } \\
\text { code }\end{array}$ & $\begin{array}{c}\mathrm{Ag} \\
\mathrm{e}\end{array}$ & Gender & $\begin{array}{c}\text { Parents } \\
\text { Status }\end{array}$ & Religion \\
\hline $\mathrm{C} 1$ & 15 & Boy & $\begin{array}{c}\text { Not } \\
\text { Divorced }\end{array}$ & Islam \\
\hline $\mathrm{C} 2$ & 14 & Boy & $\begin{array}{c}\text { Not } \\
\text { Divorced }\end{array}$ & Islam \\
\hline $\mathrm{C} 3$ & 16 & Boy & Divorced & Islam \\
\hline $\mathrm{C} 4$ & 16 & Boy & Divorced & Islam \\
\hline
\end{tabular}

The main themes discussed were the factors predisposing to involvement in drug addiction, the worldview of addiction and the effects of drug abuse on adolescents. The findings were presented below according to client code:

Client no. $1(\mathrm{C} 1)$ :

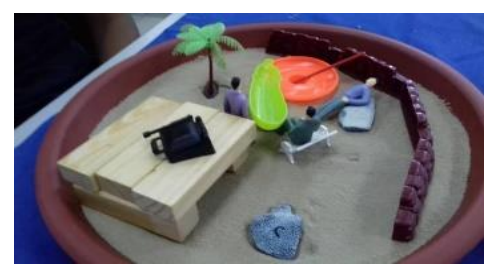

The client has taken three human miniatures, trees, addictive substance, stone and wooden blocks. Through the play therapy session, C1 created a little man as himself with two other friends who were taking drugs. The client has compiled all human miniatures in a sitting position, and in front of them are the tools used for drug abuse, such as lighters, aluminum papers and methamphetamine.The client has been involved with the world of addiction since the age of 12 . The client has a very close relationship with his friends and they have been using drugs together. The client said his friend has taught how to chase drugs (chase the dragon). Symbolically, the client described the situation that occurred during drug addiction activities in which he and his friends were in a state of euphoria ("on a high"). The client has methamphetamine (pil kuda) addiction, and his withdrawal effects were agitation and anger. The client was also addicted to Erimin 5. 


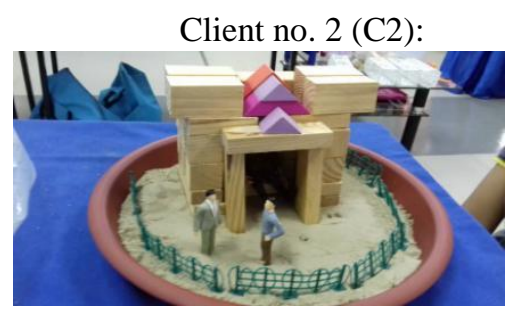

Through the play therapy modality shown by the client, the client has taken two human miniatures, fences and wooden blocks. The two human miniatures represent the client and his friend. They have been friends since the age of 12 . The client stated that they abuse drugs in the toilet. Because easier to them hide from the others students. They kept their illegal activities a secret by taking turns to guard the toilet door.

Client no. 3 (C3):

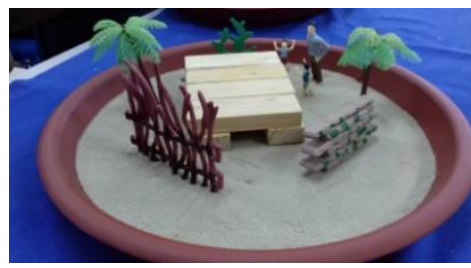

During the play therapy session, the client took three human miniatures, trees, wooden blocks and fences. The miniature human representing his friend was larger - a metaphor to show the dynamics of the relationship. The client stated that a friend was the 'leader' and often invited him to join in. They would frequently abuse drugs in the bushes, as it was hidden from peoples' view. The client has been involved in the world of drug addiction since the age of 13. He admitted that he took drugs to satisfy his own curiosity. The client also had a conflicting relationship with his family; choosing friends over family. He would get angry with his mother if she refused to give him money to buy drugs.

Client no. 4 (C4):

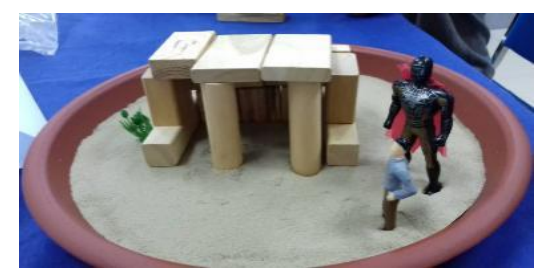

Through the picture above, the client has taken a wooden block, a human miniature and a larger-sized miniature hero. This depicts the power and control that the 'hero' has over the client. In this case, the client's 'hero' was a drug pusher. He encouraged the client to start buying drugs and they would use the drugs together. The wooden blocks constructed were huts where they engaged in drug abusing activities. His addiction emerged since the age of 14 . In his 'high' state, he claimed to feel lighter, could withstand hunger, was unafraid of other and became easily angry.
The findings of this case study are translated into Table 2 to give a clearer picture of the addictive world that is happening to each client:

Table 2: Summary of findings

\begin{tabular}{|c|c|c|}
\hline $\begin{array}{l}\text { Clients } \\
\text { code }\end{array}$ & Tools & $\begin{array}{l}\text { Factors, location addicted } \\
\text { and effects }\end{array}$ \\
\hline \multirow[t]{3}{*}{$\mathrm{C} 1$} & \multirow{3}{*}{$\begin{array}{l}\text { Human } \\
\text { miniatures, } \\
\text { trees, } \\
\text { addiction } \\
\text { tools, stones } \\
\text { and wooden } \\
\text { blocks. }\end{array}$} & Factors : Self and friends \\
\hline & & $\begin{array}{l}\text { Location : Empty } \\
\text { buildings }\end{array}$ \\
\hline & & $\begin{array}{l}\text { Effects : Often restless, } \\
\text { angry, dizziness, } \\
\text { entertained and avoid } \\
\text { scolding others. }\end{array}$ \\
\hline \multirow[t]{3}{*}{$\mathrm{C} 2$} & \multirow{3}{*}{$\begin{array}{l}\text { Human } \\
\text { miniatures, } \\
\text { fences and } \\
\text { wooden } \\
\text { blocks }\end{array}$} & Factor : friends \\
\hline & & Location :Toilet \\
\hline & & $\begin{array}{l}\text { Effects : Easily angry and } \\
\text { do not think of others }\end{array}$ \\
\hline \multirow[t]{3}{*}{$\mathrm{C} 3$} & \multirow{3}{*}{$\begin{array}{l}\text { Human } \\
\text { miniatures, } \\
\text { trees, wooden } \\
\text { blocks and } \\
\text { fences. }\end{array}$} & Factor: Friends \\
\hline & & Location : Bushes \\
\hline & & $\begin{array}{l}\text { Effects : Easily angry and } \\
\text { do not think of anyone else }\end{array}$ \\
\hline \multirow[t]{3}{*}{$\mathrm{C} 4$} & \multirow{3}{*}{$\begin{array}{l}\text { Wood block, } \\
\text { a miniature } \\
\text { man and a } \\
\text { miniature } \\
\text { hero }\end{array}$} & $\begin{array}{l}\text { Factors : drug dealers and } \\
\text { friends }\end{array}$ \\
\hline & & $\begin{array}{l}\text { Location : Huts in the } \\
\text { village }\end{array}$ \\
\hline & & $\begin{array}{l}\text { Effects : Body will feel } \\
\text { light, can withstand } \\
\text { hunger, not be afraid of } \\
\text { others, easily angry with } \\
\text { others. }\end{array}$ \\
\hline
\end{tabular}

\section{DISCUSSION}

Adolescents undergo various experiences that shape their lives. If negative experiences are not adequately explored and addressed, it may affect their future lives. Play therapy provides a therapeutic space to promote the development of critical efficiency in emotional rules to share and discuss problems encountered by clients in their social relationships (O'Connor \& Ammen, 2013). 
The results of the analysis and group counselling sessions conducted on the clients found that friends known from childhood is a driving factor for drug abuse. These friendships naturally result as peers find one another easier to understand and are both looking to have some fun.

The use of sand play therapy has helped study participants improve and nurture social relationships with their friends and family members. The use of sand therapy can be expanded in emotional, social and traumatic problems as its use has a positive impact on the client (Chang Tun Kuet, 2014). The home is the 'world' or where the children grow up, get love, protection, attention, and most importantly receive early education from parents or family members before the child goes out with other individuals at different institutions such as school and so on (Suhaizam Sulaiman \& A'dawiyah $\mathrm{Hj}$ Ismail, 2017).

The results have shown that all clients choose a hidden place to carry out drug abuse activities. The examples given included bushes, school toilets, huts and empty buildings. The researchers also identified a variety of effects of drug addiction during group counselling session. According to Utusan Malaysia's (2017) report, AADK Pahang director's, Datuk Abdul Ghani Abdul Rahman said the three ports were the poorest of the poorest housing projects (PPRT), the fishing villages and villages of FELDA which contributed to the largest percentage of drug addicts.

Researchers found that all clients had negative effects such as headaches, agitation, feeling uncomfortable, and becoming easily angered. This shows that taking drugs into the body will disturb emotions, cognitive functions and behaviour of an individual. By taking drugs, they often think that they can be someone they want. Some young people take drugs to avoid sleep. Others take it because they are bored. They take medicines to get pleasure as nothing else attracts them. Some young people take drugs because they want to rebel. They turn to drugs not for themselves, but to make a difference to others, such as their family or society in general.

\section{CONCLUSIONS}

Based on the observation and selection of miniatures by the clients in play therapy, the illustration of the objects in the session, and the counselling reports provided by the researcher, this study found that adolescents became involved in drug abuse because of peer influences, and tend to engage in substance abuse in places hidden from the public eye. Drug addiction also results in undesirable psychological effects such as restlessness, agitation, headaches and discomfort.

The therapeutic modality of play therapy in this study helped researchers focus on the factors that influence adolescent involvement in drug abuse through play therapy modality, to explore the worldview of drug addiction among adolescent drug abuse through play therapy sessions and to explore the therapeutic experience of play therapy using sand tray and facilitated researchers to see the concept through clear and interesting miniatures. The use of play therapy is faster and the results obtained are more easily understood. Therefore, this therapeutic modality should be employed and expanded in the counselling of recovering drug addicts in an initiative to reduce the rates of drug abuse in Malaysia.

\section{REFERENCES}

Chang Tun Kuet. (2014). Penggunaan Terapi Bermain Pasir Dalam Menangani Masalah Perhubungan Sosial Antara Rakan Dan Ahli Keluarga Murid Tahun Tiga. Jurnal Penyelidikan Tindakan IPGK BL Tahun 2014, 8, 1- 17.

Creswell, J. (2012). Research design: Qualitative, quantitative, and mixed methods approaches (2nd ed.). Thousand Oaks, CA: Sage.

Dunkel, C., \& Harbke, C. (2017). A Review of Measures of Erikson's Stages of Psychosocial Development: Evidence for a General Factor. Journal of Adult Development, 24(1), 58-76 https://doi.org/10.1007/s10804-016-9247-4

Hong Kian Sam, George Tan Geok Shim, Gan Siew Ling, Peter Songan, Abang Ekhsan Abang Othman, Hasbee $\mathrm{Hj}$. Usop, Mohd Razali Othman, Abang Ahmad Ridzuan, Hatta Arabi \& Shahren Ahmad Zaidi Adruce. (2011). Penyalahgunaan Bahan Di Kalangan Remaja: Satu Kajian Di Sekolah Menengah Sarawak. Jurnal Antidadah Malaysia. Jilid 8. No. 2

Jamaludin Ahmad. (2009). Salah guna dadah: Sebab, akibat, cegah dan rawat. Serdang: Universiti Putra Malaysia.

Javadi, M. \& Zarea, M. (2016). Understanding Thematic Analysis and its Pitfalls. Journal Of Client Care, 1 (1), 33-39.

Ku Suhaila Ku Johari \& Mohamad Isa. (2017). Modul Terapi Filial 7 Sesi. Perkama International. Kuala Lumpur.

Landreth, G.L. (2012). Play Therapy: The art of the relationship (3rd ed). New York: Brunner-Routledge.

Linda E. Homeyer, Daniel S. Sweeney. (2016). Sandtray Therapy: A Practical Manual

Mohammad Nasir Bistamam, Aslina Ahmad, Amelia Mohd Noor, Ahmad Jazimin Jusoh, Mohd Bazlan Mustafa, Noraini Ismail, Samsiah Mohd Jais, Faizura Rohaizad, \& Mohd Noor Idris. (2015). Profil Tingkah Laku Remaja Berisiko Mengambil Dadah. Jurnal Antidadah Malaysia.

National Anti-Drugs Agency. (2017). Drug's Informations 2017. Selangor Darul Ehsan.

Nurfarhah Mohd Najib, Mohamad Isa Amat, Ku Suhaila Ku Johari, Nor Azita Buyong, Zuriyati Seman \& Siti Aishah Mohd Ariffin. (2017). Meneroka Ketagihan Gadjet, Rokok dan Penyalahgunaan Dadah Dalam Kalangan Kanak-Kanak Melalui Intervensi Kaunseling Kelompok Terapi Bermain. Prosiding Seminar Play Therapy 2018: Kreativiti dalam Kaunseling Untuk Mendepani Cabaran Generasi Alaf Baru. 
Rusniah Ahmad, Samihah Khalil, Ahmad Nasyran Azrae, Roos Niza Mohd Shariff, Aspalela Abd Rahman, Yusramizza Md Isa. (2011). Undang-undang rawatan dan pemulihan dadah dari sudut pandangan global: Suatu perbandingan.

Suhaizam binti Sulaiman \& A'dawiyah Hj. Ismail. (2017). The Influence of Family Education atHome Among Drug Addicts: A StudyAt The Cure \& Care Vocational Centre Sepang.Jurnal Sultan Alauddin Sulaiman Shah E-Issn: 2289-8042Vol 4 Bil 1

Utusan Malaysia. (2017). Rumah kampung jadi sarang penagihan dadah

O'Connor, K.J., \& Ammen, S. (2013). Play therapy: Treatment planning and interventions. United States of America: Elsevier 